\title{
INTEGRATED ANALYSIS OF GEOLOGICAL AND GEOPHYSICAL DATA FOR THE DETECTION OF UNDERGROUND MAN-MADE CAVES IN AN AREA IN SOUTHERN ITALY
}

\author{
Sergio Negri ${ }^{1,2 *}$, Stefano Margiotta ${ }^{1,2}$, Tatiana Anna Maria Quarta ${ }^{1}$, Gabriella Castiello $^{3}$, \\ Maurizio Fedis, And Giovanni Florio $^{3}$
}

\begin{abstract}
In Cutrofiano, in the southern part of the Salento Peninsula, Apulia, Italy, a Pleistocene calcarenitic sequence was quarried by digging extensive networks of galleries along the geological succession most suitable for the quarrying activity. These caves represent a potential hazard for the built-up environment due to the occurrence of underground instability that may propagate upward and eventually reach the surface, causing sinkholes. In this work we propose integrated interdisciplinary methods for cavities detection. The methodology was applied at a test area located along a major road near Cutrofiano using geological and electrical-resistivity tomography and microgravity geophysical methods.
\end{abstract}

\section{INTRODUCTION}

Natural and anthropogenic caves represent potential hazards for the built-up environment because local instability may propagate upward and eventually cause the formation of sinkholes. The effects at the ground surface may be severe when the caves are at shallow depth. In the Apulia region of southern Italy there are many sites where underground quarrying was done in the past, due to the presence of good rocks for building purposes (Parise, 2010; Parise and Lollino, 2011). Cutrofiano is a site affected by a network of man-made cavities that underlie major roads and part of the urban center. Due to several soil collapses, sinkholes formed near roads and houses. In order to protect the potentially affected areas, the municipal and provincial authorities are very interested in evaluating the risk of collapses and tackling the problem of instability. Unfortunately, the technical information about the sinkholes is often poor and the maps of the man-made caves are incomplete, making any forecast inaccurate. In these cases, non-destructive geophysical methods can play an important role in identifying and mapping the unknown cavities.

In scientific literature, many papers report on the successful application of geophysical prospecting for the detection of natural cavities: Gibson et al. (2004), Leucci et al. (2004), Mochales et al. (2008), Kaufmann et al. (2011), Gambetta et al. (2011), Gómez-Ortiz and Martín-Crespo (2012) and Pueyo Anchuela et al. (2013). This is probably because natural cavities are often isolated, with a high contrast between their physical parameters and those of the host material. Applications of geophysical prospecting in areas of abandoned networks of manmade cavities are less frequent: Margiotta et al. (2012), Martinez-Lopez et al. (2013), Martinez-Pagan et al. (2013), Bianchi Fasani et al.
(2013), and Kotyrba and Schmidt (2014). In these more complex cases, we propose the application of integrated interdisciplinary methods that consist of creating a conceptual hydrostratigraphical model using geological data like quarry plans and boreholes, selection of geophysical methods appropriate to the physical parameters of the setting to obtain detailed subsurface information, planning of boreholes based on the geological and geophysical results, and matching of the hydrostratigraphic and geophysical models, constrained by boreholes data, to obtain a detailed characterization of the subsoil and successful quarry location.

This methodology was applied to a test area near an important road that links Cutrofiano to Collepasso and Supersano that is probably at risk by the presence of quarries, whose floor plans are, however, unknown.

\section{Morphological and Historical Setting}

The study area in Cutrofiano (Fig. 1) is located in southern Apulia at an average altitude of about $100 \mathrm{~m}$ above sea level. Here, the Pleistocene calcarenite, a typical soft rock, was quarried by digging extensive networks of underground galleries that followed the levels within the local geological succession most suitable for the quarrying activity (Fig. 2). Extraction employed manual tools in the past and mechanical tools in more recent times. Some of the oldest quarries reveal areas excavated both by hand and mechanically. The blocks of stone were removed so as

\footnotetext{
${ }^{1}$ Department of Biological and Environmental Science and Technologies (DiSTeBA), University of Salento (Italy)

${ }^{2}$ GEOMOD S.r.l. Spin-off, University of Salento

${ }^{3}$ Dipartimento di Scienze della Terra, dell'Ambiente e delle Risorse, Università Federico II di Napoli (Italy)

*Corresponding author: sergio.negri@unisalento.it (Sergio Negri)
} 

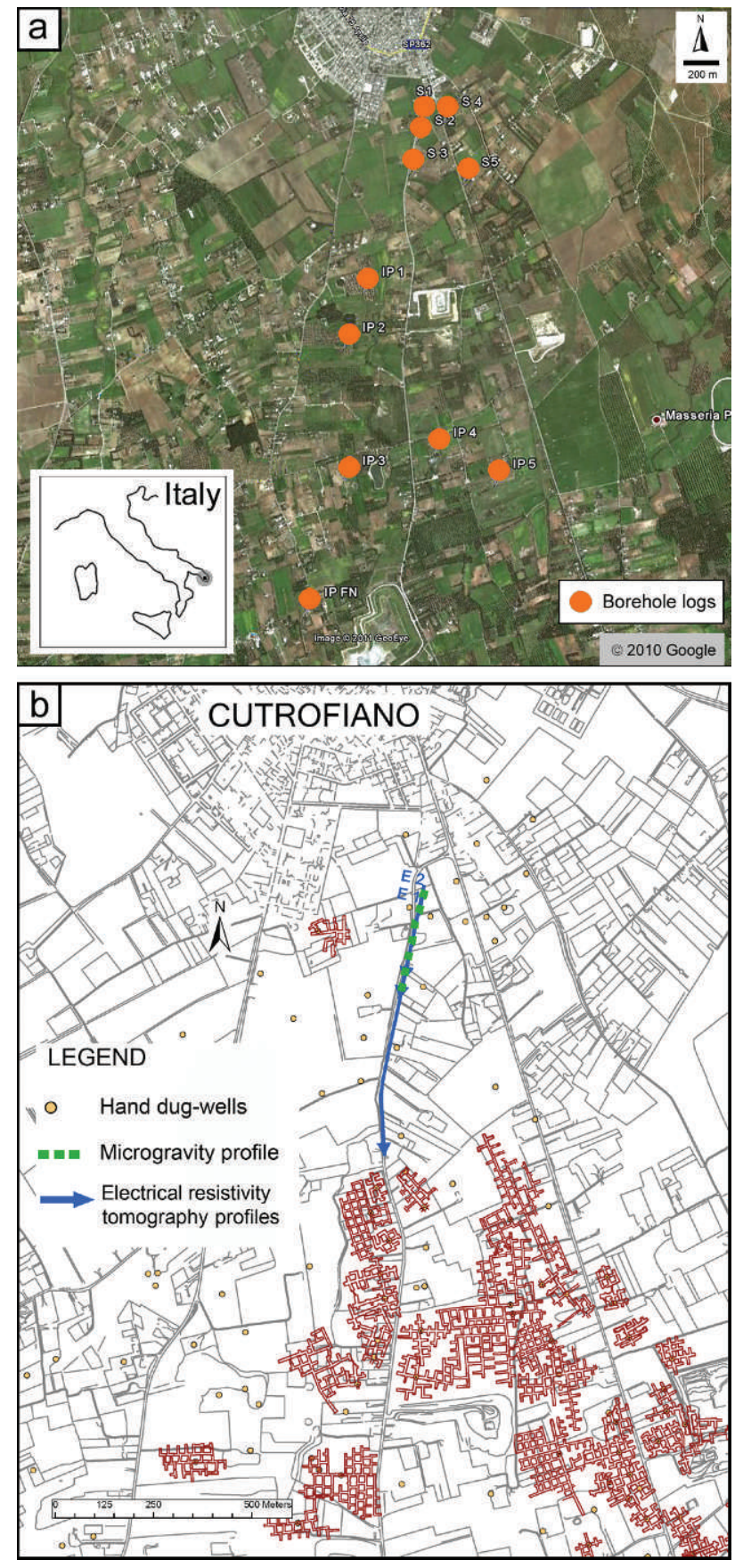

Figure 1. (a) Aerial view of the study area, with boreholes that provided stratigraphic information shown. The holes S1, S2, and S3 were drilled as part of this study and are described in the text. (b) Map of the area, with known, surveyed parts of the quarry networks shown. The hand-dug wells hint at the extent of unknown quarries. The paths of the electrical-resistivity surveys are shown in blue, E1 being the longer line and E2 being the top portion. The microgravity profile extended along the part of the traverses as indicated, but many more points were measured.
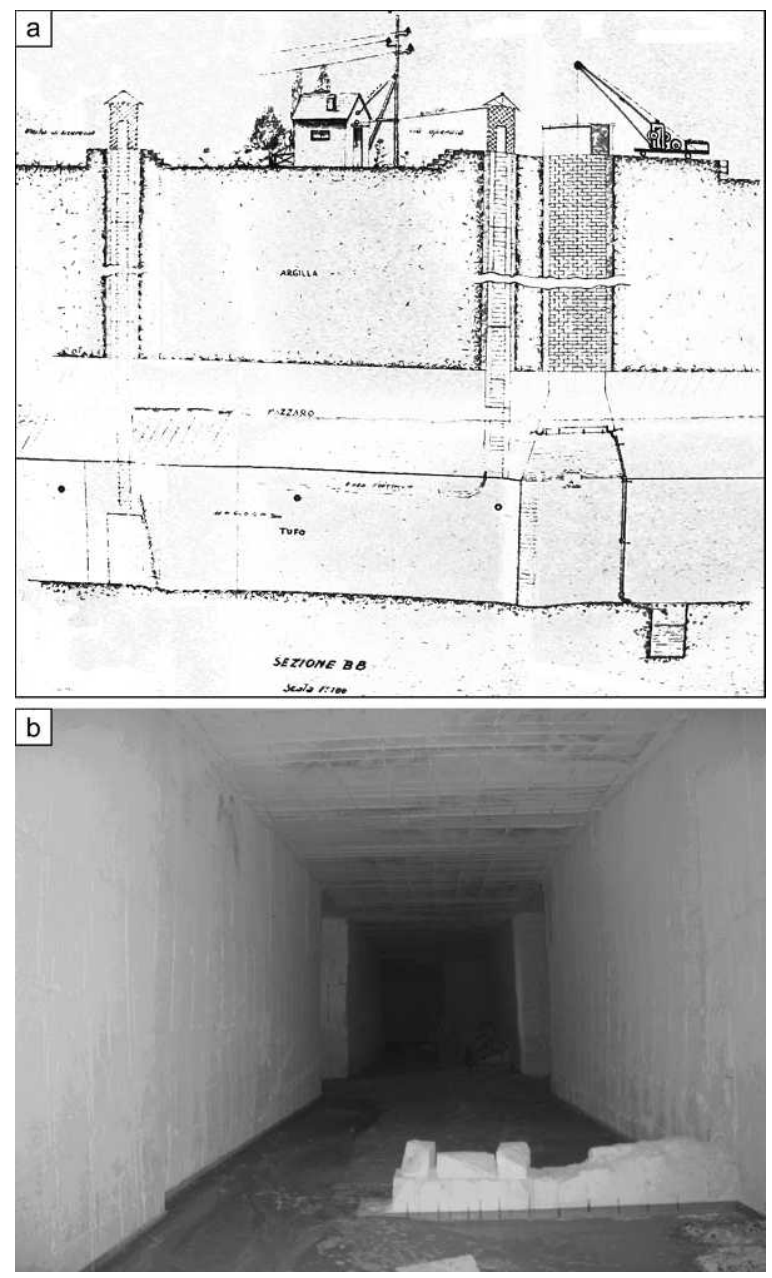

Figure 2. (a) Old drawing of quarry tunnel with hand-dug wells for access (filed at the Municipality of Cutrofiano) (b) Photo of quarry tunnels, with intersection in the distance.

to leave lines of pillars in a more or less regular way and aligned to support the roof of the excavated cavity. The initial geometry of the quarries was a chessboard with tunnels and lines of pillars arranged orthogonally to each other. Subsequently, after the first cases of subsidence, the mining office of Apulia advised a plan with staggered pillars. While this arrangement of the supporting structure makes the transport operations of quarry materials slower and more difficult, it gives greater stability to the roof of the tunnels. The tunnels are of variable size (Bruno and Cherubini, 2005; Parise and Lollino, 2011), 5 to $6 \mathrm{~m}$ wide, 6 to $8 \mathrm{~m}$ high, with a maximum observed of $10 \mathrm{~m}$, and length greater than $20 \mathrm{~m}$ (Figure 1b). The presence of underground cavities is indicated on the surface by the hand-dug wells by which the quarrymen reached the calcarenitic sequence and removed quarried material.

If the network is accessible and well preserved, an underground geological and topographical survey may completely define the location within the local stratigraphy

Journal of Cave and Karst Studies, April 2015 •53 

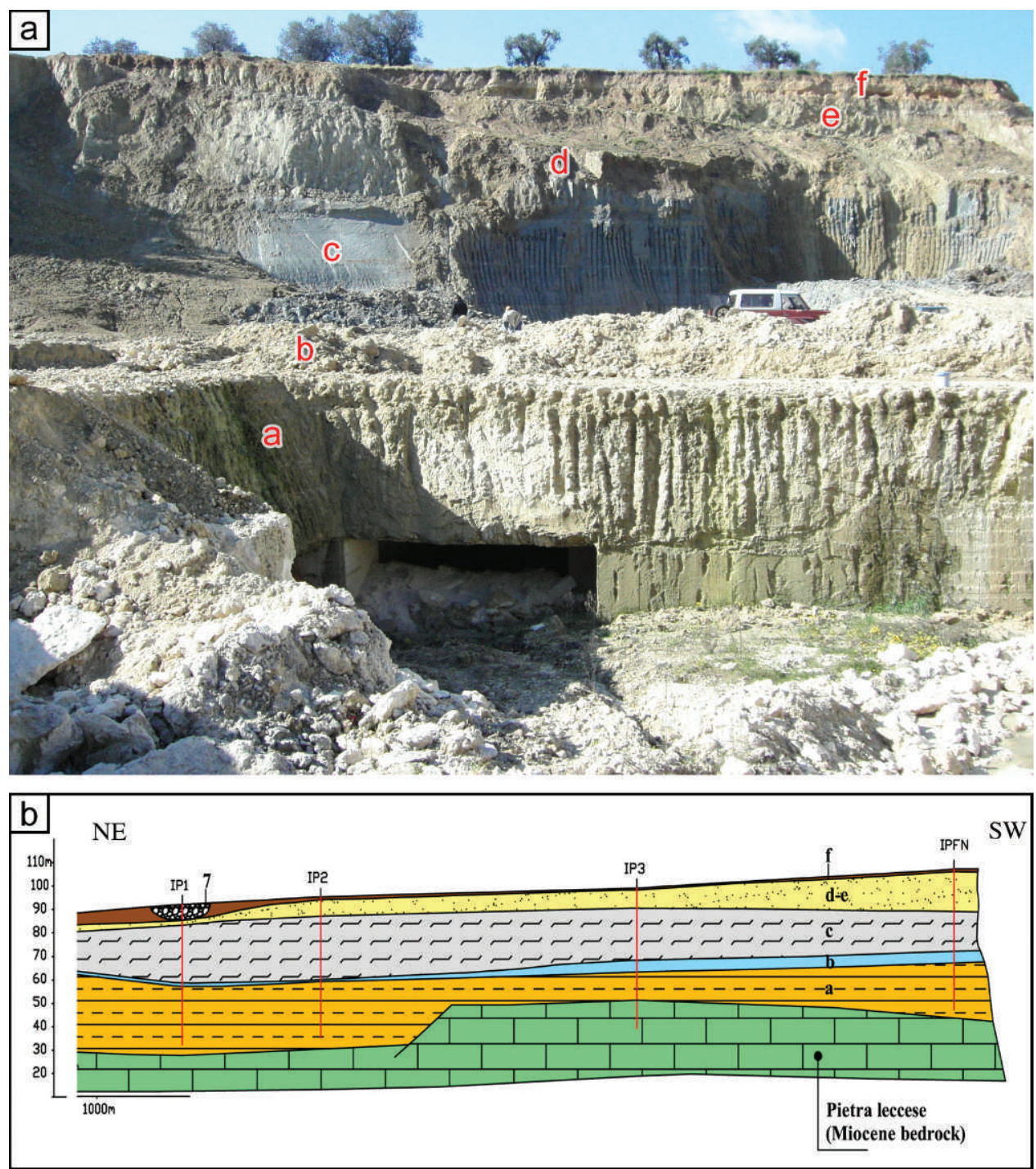

Figure 3. (a) Photograph of modern Signorella quarry some distance south of the geophysical traverses, showing the stratigraphy there. (b) Geological section, based on boreholes with locations shown in Figure 1a. In both parts, the units are a, the Gravina Calcarenite overlying the Miocene basement rock; b, the Brachiopods sands; $c$, the Subapennine clays; $d$, the Brindisi sands; e, Terraced deposits; and f, top soil.

and the position of the galleries (Parise and Lollino, 2011). In this case, the physical parameters that are needed for a complete soil characterization are estimated on the basis of high-quality samples collection and high-resolution boreholes. However, the underground activities in Cutrofiano have been progressively abandoned, and many quarries have been used for other purposes, including illegal discharge of solid and liquid wastes, making many of the galleries inaccessible. Geophysical surveys could be suitable for developing a model of the subsoil before drilling (Bianchi Fasani et al., 2013). To identify single cavities, it is necessary to drill with a spacing less than the tunnel size. As a consequence, a high number of boreholes and a considerable expense are required.
Instability of underground cavities, resulting from the progression of deformation in the quarried rocks, can involve the whole rock mass overlying the cave, thus giving rise to a true sinkhole or to a subsidence phenomenon (Parise, 2012). In other cases, only small portions of the rock mass around the cave are initially involved, with local failures that may induce a gradual and progressive enlargement or increase of the height of the cave, up to a critical configuration that later can develop into the complete collapse of the rock mass (Parise and Lollino, 2011). Currently in Cutrofiano, the shallow layers of clay are quarried at many sites (Fig. 3a); for this reason, the roads are intensely traveled by heavy vehicles carrying quarried material, likely contributing to increase in the risk of collapse (Fig. 4). 

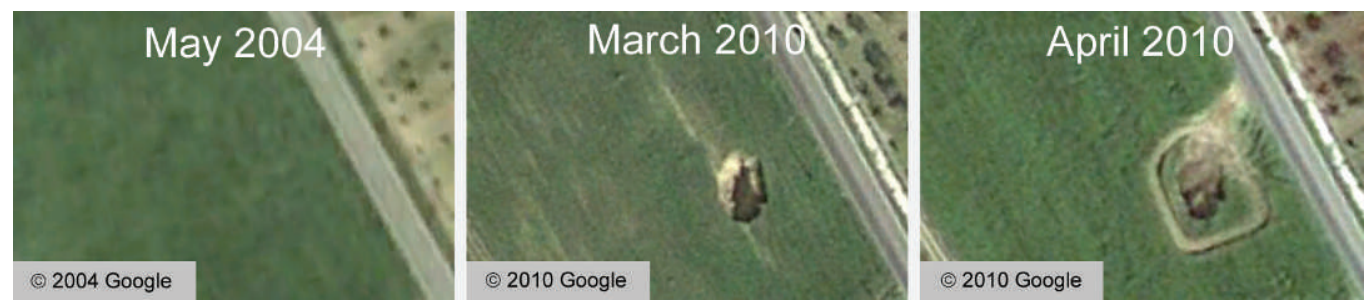

Figure 4. The development of a sinkhole near a road in the area.

\section{HYDROSTRATIGRAPHY}

The conceptual hydrostratigraphic model was developed using a large set of data provided by our initial field surveys: geological data (Margiotta and Varola, 2007), plans of the quarries, borehole and water-well data, laboratory analyses, and critical revision of well-core stratigraphies supplied by local agencies and professionals. From the stratigraphic point of view, five separate units above the Cretaceous and Miocene bedrock are recognizable (Fig. 3). From the most ancient to the most recent, they are:

(a) The Gravina Calcarenite (Ricchetti et al., 1988) is the most ancient of the Early Pleistocene formations of the area. This unit, transgressive on the Pietra leccese Formation of Miocene age, consists of yellow or white coarse-grained calcarenite with abundant fossils (Cardium, Glycymeris, Pecten). The natural water content varies with an average value of $30 \%$, with the porosity index varying between 0.5 and 0.7 . This unit is the one quarried.

(b) Brachiopods sands (D'Alessandro et al., 1994, 2004), a greenish clayey-sandy interval a maximum of 4-m thick overlying the Gravina Calcarenite with an irregular erosive surface. A transgressive lag, up to $50-\mathrm{cm}$ thick, characterized by an abundant concentration of randomly oriented casts of both articulated and unmatched bivalve shells (such as Arctica islandica, Pecten jacobeus, Acanthocardia sp., Terebratula ampulla, and Terebratula scilla,....), gastropods, rhodolits, and Ditrupa tubes, overlies the erosional surface.

(c) Subapennine clays (Early Pleistocene) are characterized by blue-gray clayey silts, rich in fossils such as Arctica islandica, Pecten jacobaeus, Aequipecten opercularis, Dentalium rectum, and Mya truncata, both dispersed in the sediments and concentrated in continuous decimeter-thick intervals. The contact with brachiopods sands is sharp and indicated by a decimeter-thick hard ground covered by a reddish, sandy interval including a horizontally developed Thalassinoides system.

(d) Brindisi sands are composed of fine-grained sands whose color shifts from gray to yellow or light brown moving upward; these sands contain abundant diagenetic concretions that are aligned in the upper part and became scattered downwards. The granulometry of the sandy facies, in terms of gravel $(<5 \%)$, and clay $(<10 \%)$, varies depending on the stratigraphic level. The contact with subapennine clays is characterized by an undulating erosional surface. The lower part of this formation is made up of gray clayey sandy silts, with carbonaceous fragments with common presence of fossils of Arcticidae, Cardiidae, Pectinidae, and Nuculidae. The stratification is indistinct. The age, according to its stratigraphic position, is Early-Middle Pleistocene.

(e) Terraced deposits from the Middle-Upper Pleistocene are lithologically composed of yellowish coarsegrained biocalcarenites rich in ostreids, with sandy layers or layers of organogenic limestones varying in thickness from a few centimeters to $15 \mathrm{~cm}$. The contact with Brindisi sands is characterized by an abrupt lithological variation from diagenetic calcarenite to sands.

The densities of these lithological units are listed in Table 1. The Pleistocene deposits are covered by soil (f) that lies over almost all the area examined. The thickness of the soil varies considerably, from a few decimeters to about $5 \mathrm{~m}$, although the most frequent values are in the range of 1 to $2 \mathrm{~m}$.

On the basis of the previously described stratigraphy, the Cutrofiano area shows two overlapping and hydraulically independent aquifers. A deep aquifer lies in the Mesozoic Altamura Limestone hydrogeologic unit, made up of fractured and karstic carbonatic rocks (Giudici et al., 2012). A deep fresh water aquifer overlies more dense seawater, and the thickness of this fresh water above the interface with saline water can be estimated based on the

Table 1. The specific weights of the stratigraphic units underlying the study area.

\begin{tabular}{lc}
\hline Lithostratigraphic Units & Specific Weight $\gamma\left(\mathrm{kN} / \mathrm{m}^{3}\right)$ \\
\hline Terraced deposits & 19.50 \\
Brindisi sands & 18.93 \\
Subapennine clays & 19.40 \\
Brachiopods sands & 18.44 \\
Gravina Calcarenite & 15.49 \\
\hline
\end{tabular}


relationship of Ghyben-Herzberg. Unlike the shallow groundwater, found only in places, the deep groundwater extends across the whole of the Apulia region. The deep aquifer, lying below the miocenic Leccese Pietra, contains water under pressure and is, therefore, artesian.

There is also a shallow, porous aquifer formed by the Middle-Upper Pleistocene marine calcarenitic and sandy deposits overlying the lower Pleistocene clays. This aquifer is phreatic, with semiconfined conditions where its upper part is overlain by recent sediments of low permeability. Based on lithostratigraphy, this aquifer can be subdivided into several hydrogeologic units. The Early Pleistocene subapennine clays constitute the impermeable base of the aquifer, with groundwater velocities of only $3 \times 10^{-7} \mathrm{~m} \mathrm{~s}^{-1}$ (Margiotta et al., 2010). The Pleistocene aquifer system involves two hydrogeologic units. The greatest permeability is found in the terraced deposits from the Middle-Upper Pleistocene. As the fraction of silt increases, the permeability of the deposit decreases. The lower section of the aquifer, the silty-sandy sediments of the Early-Middle Pleistocene Brindisi sands hydrogeologic unit, has low permeability. The shallow aquifer flows towards Cutrofiano, but the lack of homogeneous distributed and contemporaneous data does not permit the development of a piezometric map.

\section{Geophysical Methods}

The main objective of the geophysical survey was to identify unknown cavities along the road shown in Figure 1b. In the case of Cutrofiano, there are difficulties linked to the presence of an aquifer and the required resolution for the detection of voids less than 10-m high and wide, though greater than $20-\mathrm{m}$ long, located from $7-\mathrm{m}$ to $40-\mathrm{m}$ depth. These factors, and particularly the presence of conductive materials such as silty and clayey layers, have driven the choice of the methods. In this context, one of the most suitable method for our aim is the electrical-resistivity tomography (Loke, 2014; Reynolds, 1997). ERT is sensitive to resistivity changes in the subsoil and it allows a good investigation depth in the presence of conductive materials, unlike ground-penetrating radar (Jol, 2009). Furthermore, ERT has good resolution and it is expeditious. One other suitable method is microgravity, which is very sensitive to density changes between the cavities and the host material, and so is able to detect voids (Reynolds, 1997). We decided to use both methods in the test area, in order to perform an integrated interpretation to improve on the information from each individual method.

\section{RESISTIVITY SURVEY}

Electrical-resistivity measurements were made by using an IRIS SYSCAL R1 (48 electrodes). These measurements, acquired along the survey line, produce an apparent resistivity cross-section (Reynolds, 1997) based on the subsoil electrical properties. Apparent resistivity data are then inverted to generate a resistivity model of the subsurface structures and stratigraphy. In general, the Wenner array allows high-resolution whenever horizontal structures are involved. The dipole-dipole array instead is preferred to map vertical structures, such as dykes and cavities (Dahlin and Zhou, 2004). The acquisition parameters were chosen according to the degree of resolution required, taking into account the depth of the calcarenite with the quarries in the investigated area (Fig. 3). For ERT investigations, the electrode spacing ranged $5 \mathrm{~m}$ to $10 \mathrm{~m}$, depending on the depth target and the required resolution. We carried out two profiles labelled E1 and E2, placed along the roadside (Figure 1b). ERT E1 was performed to search for the cavity in ranges depth $8 \mathrm{~m}$ to $40 \mathrm{~m}$, while the $\mathrm{E} 2$ line employed a shorter electrode spacing of $5 \mathrm{~m}$ for enhanced resolution of the near-surface to search for the cavities.

We first carried out the profile E1, 670-m long, joining one roll-along, starting at $200 \mathrm{~m}$, multi-channel acquisition with an electrode spacing $10 \mathrm{~m}$ and reaching an investigation depth of about $50 \mathrm{~m}$, because we expected the calacarenite at about $30 \mathrm{~m}$ depth (Figure 3b). The maximum depth reached, max, depends on the electrode arrays used. For Wenner and dipole-dipole arrays, this max depth is estimated as $0.2 \times \mathrm{L}$, L being the total length of the E1 $(470 \mathrm{~m})$. In our case, with the beginning of the roll-along at $200 \mathrm{~m}$, we investigated to a depth of about $50 \mathrm{~m}$ because the maximum depth that ensures a continuity of the bottom part of the image is about one half the max (Bernard et al., 2014).

Later we carried out the profile $\mathrm{E} 2$ with a $5 \mathrm{~m}$ electrode spacing to improve the resolution. Both dipole-dipole and Wenner array (Reynolds, 1997) were performed to obtain information for both quarries and stratigraphy.

The tomographic inversion was performed using RES2DINV (Geotomo Software) with the L2-norm leastsquares optimization method, the smoothness-constrained by deGroot-Hedlin and Constable (1990), and model cells with widths of half-unit spacing. The topographic effect was taken into account, because there is an elevation difference of about $5 \mathrm{~m}$ along the E1 profile.

The electrical model shows a range of resistivity values, from 10 to more than $4000 \mathrm{ohm} \mathrm{m}$ and a RMS errors of $3.6 \%$ (Wenner), 5.8\% (dipole-dipole, spacing $10 \mathrm{~m}$ ), and $8.6 \%$ (dipole-dipole, spacing $5 \mathrm{~m}$ ) after five iterations (Fig. 5). The choice to stop the data inversion procedure at the result of the first iteration is due to the unchanged value of RMS error in additional iterations.

\section{Microgravity Survey}

To reduce the uncertainty in interpreting the electricalresistivity tomography profile, we decided to carry out a microgravity survey along the first part of the E1 ERT profile (Figure 1b). The measurement stations were planned according to the expected dimensions and depth of the target and after considering the results of synthetic models of the caves designed on the basis of the available 

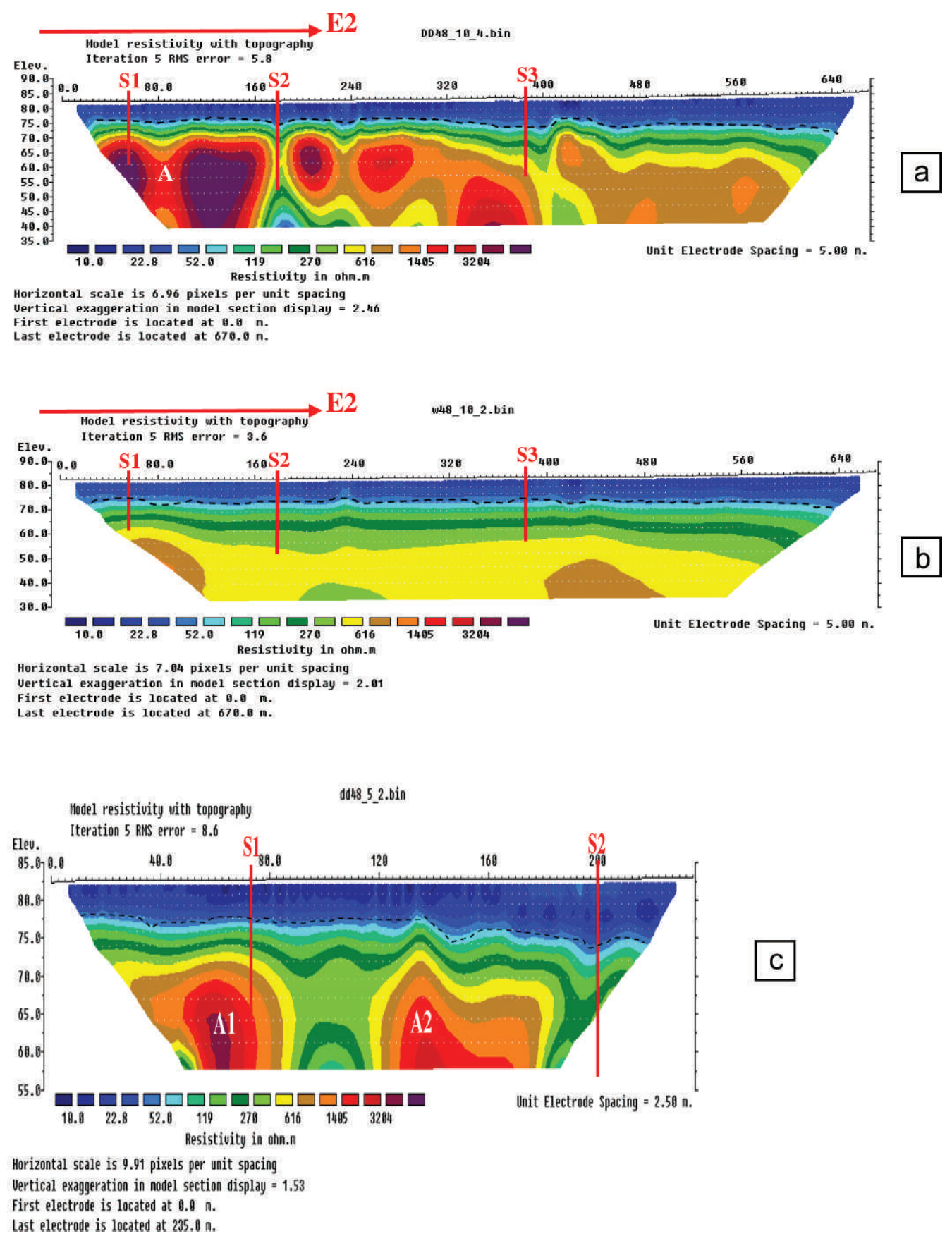

Figure 5. 2-D profile results of electrical-resistivity tomography. (a) Traverse E1 with dipole-dipole array, $10 \mathrm{~m}$ spacing. (b) Traverse E1 with Wenner array, 10-m spacing. (c) Shorter E2 traverse with $5 \mathrm{~m}$ spacing to obtain better detail on the high-resistivity areas shown as $\mathrm{A}$ in part (a) and $\mathrm{A} 1$ and $\mathrm{A} 2$ here.

geological and ERT information. The data were acquired along the profile $\mathrm{P} 1$, with a variable sampling step from $3 \mathrm{~m}$ to $6 \mathrm{~m}$, yielding a total of 68 observations (Fig. $6 \mathrm{a}$ ).

The gravity survey was conducted using an Auto-Grav Scintrex CG5. At least three values of gravity were stored at each station; each measurement lasted 60 seconds. For measurements performed on the roadway, due to the noise associated with vehicular traffic, the number of readings was increased to nine or twelve, until the repeatability was satisfactory. The repeatability was judged satisfactory when the difference between the readings at a station was not greater than 5 microGal. Measurements were repeated at a base station about every hour to sample the instrumental drift curve. The base station (green circle in Fig. 6a) was located along the profile $\mathrm{P} 1$ at station number 19. Simultaneously, a topographic survey was carried out, by measuring the elevation differences at each station using differential GPS. Station number 12 was 



Figure 6. (a) The gravity profile along traverse P1. The location of the borehole $\mathrm{S} 1$ is shown. The green line indicates the position of one conspicuous low. The green dot is the station visited repeatedly to correct for instrument drift. (b) The second vertical derivative of the data at ground level; compare to Figure 7a.

located close to the borehole S1 (Figure 6a) in correspondence of the resistivity anomaly A1 (Fig. 5c). The data were corrected for tidal and instrumental drift effects, and free-air and complete Bouguer anomalies (Fig. 6a) were computed (Talwani et al., 1959), taking into account that the maximum elevation difference is $1.89 \mathrm{~m}$ and using a plate density of $1.9 \mathrm{~g} \mathrm{~cm}^{-3}$, according to the stratigraphy data in Fig. 3b.
Actually, buildings near the profiles represent the main topographical disturbance in the area. The main walls of the buildings were modelled by thirty prisms and their gravity effect computed by using a density contrast of $2.5 \mathrm{~g} \mathrm{~cm}^{-3}$, since walls are generally made of the same calcarenite present at depth in the area. A water-collecting channel was also modelled; the density contrast chosen for it was $-1.9 \mathrm{~g} \mathrm{~cm}^{-3}$. 
To reduce the trend effect, we computed the second vertical derivative of the Bouguer anomalies at ground level (Figure 6b) and upward continued it up to $30 \mathrm{~m}$ (Fig. 7a) to reduce the high-frequency noise enhancement related to the field differentiation. The depth-fromextreme-points (DEXP) method (Fedi, 2007) was then used to yield an image of the source distribution (Fedi and Pilkington, 2012), in which the maxima or minima define the top or the mean position of the sources (Fig. 7b). It allows also the estimation of the structural index $N$, a source parameter related to the general shape of the source. For gravity anomalies, $N$ is equal to 2 for a spherical source, 1 for a cylindrical source, and 0 for a thin dyke or sill, tending to -1 for a fault. In our case, it is appropriate to approximate the shape of underground caves with horizontal cylinders.

\section{RESUlts AND Discussion}

Electrical-resistivity data inversion allowed us to obtain a possible resistivity model, and the DEXP method applied to the microgravity data has located the possible sources of Bouguer anomalies. The resistivity models (Fig. 5) show two main layers. The first layer is conductive, with resistivity values in the range 10 to $50 \mathrm{ohm} \mathrm{m}$ and thickness of about $5 \mathrm{~m}$ (Fig. 5a). The model from the E1 Wenner profile in Figure $5 b$ shows increasing thickness of this layer going southward. The second layer is resistive, with resistivity values in the range 600 to $5000 \mathrm{ohm} \mathrm{m}$. In Figure 5a, the strongest resistivity anomaly along profile $\mathrm{E} 1$ is labelled A, at a distance of about $120 \mathrm{~m}$. We carried out the dipole-dipole array profile E2 to better define anomaly A, using a $5 \mathrm{~m}$ electrode-spacing that allowed for improved resolution. The model from the E2 profile shows the anomaly $\mathrm{A}$ as two distinct anomalies $\mathrm{A} 1$ and $\mathrm{A} 2$ (Fig. 5c).

The Bouguer anomalies along the microgravity traverse are shown in Fig. 6a. A gravity anomaly of about $0.07 \mathrm{mGal}$ is present between $0 \mathrm{~m}$ and $57 \mathrm{~m}$, indicated by the green line. From 57 meters to 85 meters there is a gravity high, and from 85 meters to 273 meter, the end of the gravity data, we can see a regular decrease of the gravity-anomaly field. This trend may be interpreted as a regional trend and may mask anomalies characterized by small wavelengths.

The upward-extrapolated anomalies in Figure $7 \mathrm{a}$ are much clearer, and the main features are the four anomalies indicated as A, B, C, and D. The white dots in the DEXPcalculated section in Figure $7 \mathrm{~b}$ show the estimated depths of the low-density sources, in blue, of the dips in the curve in 7a. The top of the source anomaly A in Fig.7a, in correspondence of the resistivity anomaly A1 in Fig.7c is at about 10-m depth. The source of the anomaly D in Fig.7a is at the same depth of A. The tops of sources of the gravity anomalies at $\mathrm{A}$ and $\mathrm{D}$ in Figure $7 \mathrm{a}$ are located at about 10-m depth; the anomaly $\mathrm{A}$ is at a location corresponding to electrical-resistivity high A1 in Figure $5 \mathrm{~b}$ or $7 \mathrm{c}$. The anomalies associated with areas $\mathrm{B}$ and $\mathrm{C}$ in Figure $7 \mathrm{a}$ are due to shallow sources located at about 4-m depth or laterally located. The resistivity models in Figure 5 show a strong resistivity break between the first and the second layers at a mean depth of $6 \mathrm{~m}$ below ground level.

On the basis of the geological section in Figure $3 b$ we expected the Gravina Calcarenite, where the quarries are present, to be at a depth from $20 \mathrm{~m}$ to $30 \mathrm{~m}$ below ground level. Therefore, that geological section, compiled on the basis of other observations, is not able to describe the geology in the survey area.

By a theoretical point of view of voids, we are likely to expect a gravity low coupled to resistivity high; on the other hand, for unexcavated mine pillars, we expect an increase in the Bouguer anomaly and decreasing resistivity values. We located boreholes S1 and S2 along the traverse at locations demonstrating both these features. Hence, we located borehole $\mathrm{S} 1$ at about $72 \mathrm{~m}$, corresponding to the first gravity low A in Figure 6a and the resistivity high A1 in Figure 7c. The borehole S2 was located at about $200 \mathrm{~m}$ at a resistivity low and a gravity high (Figs. $7 b, c)$. This last choice also took into account the E1 resistivity profile in Figure 5a that shows a zone at about $180 \mathrm{~m}$, between two resistivity highs, where probably there are no quarries.

The borehole S3 was located taking into account only the ERT model (lacking the gravity survey) relative to E1 (Figure 5a). We planned other boreholes at the resistivity highs between $200 \mathrm{~m}$ and $400 \mathrm{~m}$. Unfortunately, due to the presence of obstacles on the roadside, it was not possible to reach this goal. However, we did locate borehole S3 along the E1 traverse on the basis of only the resistivity model, since the gravity data did not reach its location. On the basis of the geological data, geophysical models, and core data from the S1, S2, and S3 boreholes, we realized a detailed interpretative geological model (Fig. 7d).

Along our traverse, the terraced deposits are some meters thick, with an average of $2 \mathrm{~m}$. The thickness of Brindisi sands varies from 2 to $3 \mathrm{~m}$, compared to 7 to $8 \mathrm{~m}$ a few kilometers south (Fig. 3b). The thickness of the subapennine clays varies greatly. Specifically, it increases moving southward from Cutrofiano, where it is absent or only decimenters thick at the northern limit of the investigated area, to the Signorella locality to the south, where it averages 12-m thick (Figs. 3a,b). These three units constitute the first resistivity layer; the resistivity values are affected by the presence of the aquifer that does not allow discriminating the lithological changes. The E1 Wenner traverse profile in Figure $5 \mathrm{~b}$ shows increasing thickness of this layer going southward, in agreement with the detailed model of the subsoil (Fig. 7d).

The thickness of the Gravina Calcarenite varies considerably and reaches maximum values of more than $30 \mathrm{~m}$. Moving from our traverse at Cutrofiano to the south, the top of the Pleistocene calcarenite deepens from $5 \mathrm{~m}$ (Fig. 7d) to over $30 \mathrm{~m}$ (Fig. 3b). This unit, together 

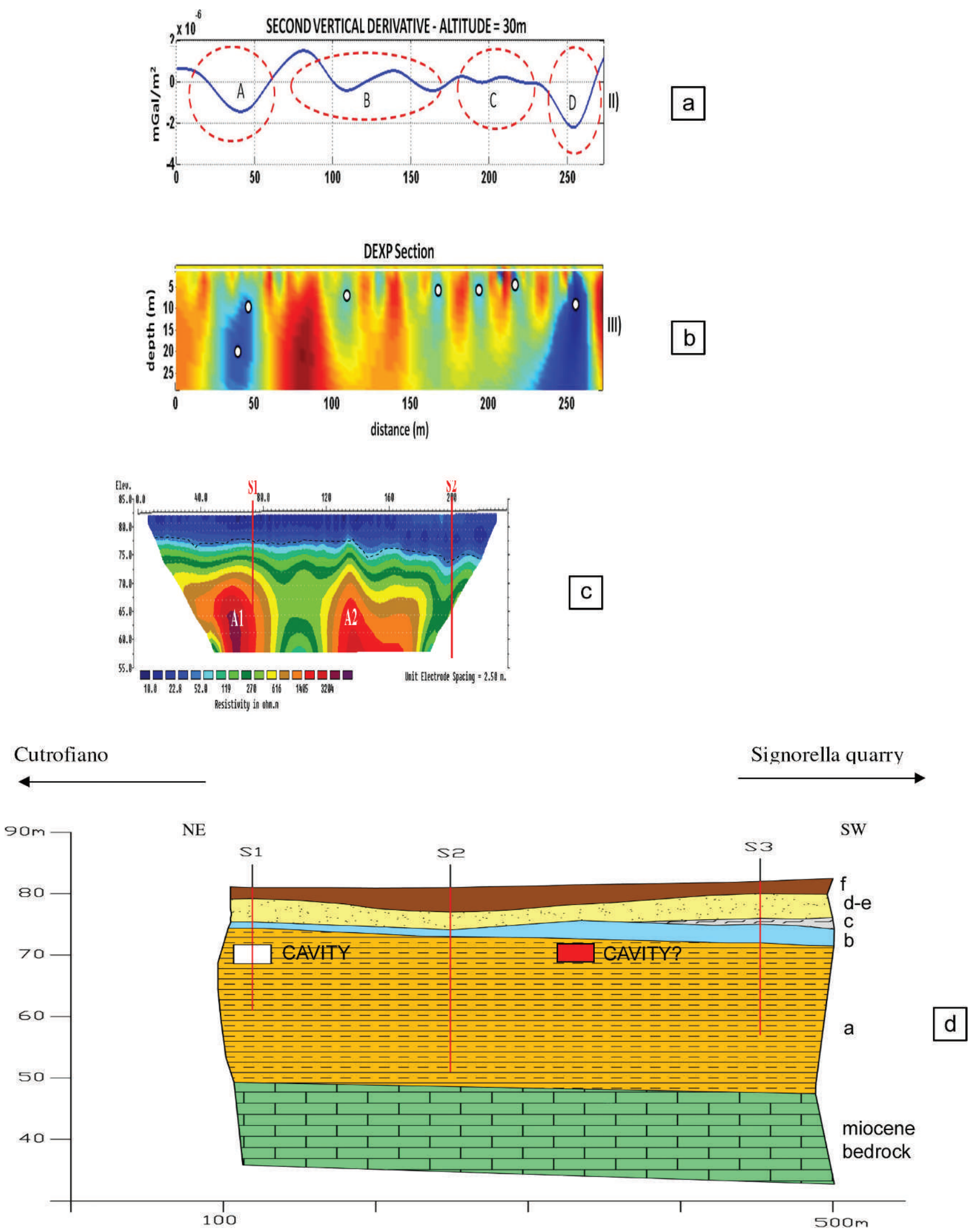

Figure 7. (a) The second vertical derivative of the gravity data extrapolated to a height of $30 \mathrm{~m}$; compare to Figure $6 \mathrm{~b}$. Regions of anomolous lows are circled. (b) Subsurface model derived from the gravity data using the DEXP (depth-fromextreme-points) method, with white dots showing the depths. (c) Electrical-resistivity tomography result for traverse E2; 
with the brachiopods sands, corresponds to the second resistivity layer.

The greatest relative minima in Fig. $7 \mathrm{a}$ are those in regions $\mathrm{A}$ and $\mathrm{D}$. The $\mathrm{S} 1$ drilling (Figure $7 \mathrm{~d}$ ) confirmed the presence of a void at a depth between $9.5 \mathrm{~m}$ and $12.5 \mathrm{~m}$, consistent with the resistivity high A1 (2000 to $4000 \mathrm{ohm}$ $\mathrm{m}$, Fig. $7 \mathrm{c}$ ) and the gravity low A. The gravity low at D, near the location of a resistivity high at $265 \mathrm{~m}$ (Fig. 5a), could be due at a cavity located at about $10 \mathrm{~m}$.

The conjectured cavity is shown at more like $340 \mathrm{~m}$ in Fig. $7 \mathrm{~d}$. The smaller gravity anomalies $\mathrm{B}$ and $\mathrm{C}$ located between $100 \mathrm{~m}$ and $240 \mathrm{~m}$ in Figure 7a correspond to resistivity highs in Figures $5 \mathrm{a}$ and $7 \mathrm{c}$, but the sources are at a shallower depth of about $4 \mathrm{~m}$, according to the gravimetry model in Figure $7 \mathrm{~b}$. If these sources were directly below the traverse, they would not be located in the Gravina Calcarenite, so we may suppose that these anomalies correspond to caves located off to the side of the road in a maze of tunnels like those shown in Figure 1b.

\section{Conclusions}

This study tried to ascertain the validity of an integrated approach, based on geophysical and geological methods, for the identification of the spatial distribution and extension of underground man-made cavities. Where the galleries are not accessible, non-destructive geophysical methods can have an important role in locating the unknown cavities and providing an interpretative model of the subsoil.

Detailed stratigraphic knowledge helps in the correct choice of the geophysical methods. Detailed stratigraphic analysis was carried out by means of soil and subsoil surveys, integrated by critical review of the data available in the literature. Results of our new geophysical studies supplement the stratigraphic model of the Cutrofiano area previously presented in literature (Parise and Lollino, 2011) with new data; the decametric thickness of subapennine clays observed in the subsoil immediately south of the area here studied are absent or have a decimetric thickness near the urban center of Cutrofiano. The detailed knowledge of the local stratigraphy was crucial for the interpretation of the geophysical surveys and is a mandatory step to properly focus subsequent studies to detect underground caves and mitigation or recovery projects.
Joint interpretation of electrical-resistivity and microgravity data was effective in reducing the uncertainty about the possible presence of cavities in the subsoil. The borehole data, used to validate and interpret the geophysical results, show that the presence of cavities in the subsoil is signaled by strong gravity lows and resistivity highs; on the other hand, with a resistivity low and gravity high we found an undisturbed zone, presumably a pillar in the cave network. The geophysical surveys and core data improved the previous geological knowledge. The resolutions of the methods worsen where there are caves located to the side of the road. In this last case, additional 2D surveys would be required to reduce the uncertainty and obtain a 3D model of the subsoil.

\section{ACKNOWLedGements}

This research work has been funded by a grant from the Province of Lecce and performed by GEOMOD S.r.l Spinoff University of Salento. The authors would like to thank the Province of Lecce and the municipal authorities of Cutrofiano for their logistics support. The authors also acknowledge the assistance provided by Massimo Luggeri in the figures.

\section{REFERENCES}

Bernard, J., Leite, O., and Vermeersch, F., 2014, Multi-electrode resistivity imaging for environmental and mining applications, technical note, IRIS Instruments, Orléans, France, www.iris-instruments.com/ Pdf\% 020 file/5-Resistivity_Imaging/Resistiivty_Imaging_text.pdf, [accessed in May 2014].

Bianchi Fasani, G., Bozzano, F., Cardarelli, E., and Cercato, M., 2013, Underground cavity investigation within the city of Rome (Italy): A multi-disciplinary approach combining geological and geophysical data: Engineering Geology, v. 152, p. 109-121. doi:10.1016/j.enggeo. 2012.10.006.

Bruno, G., and Cherubini, C., 2005, Subsidence induced by the instability of weak rock underground quarries in Apulia: Giornale di Geologia Applicata, v. 1, p. 33-39. doi:10.1474/GGA.2005-01.0-04.0004.

Dahlin, T., and Zhou, Bing, 2004, A numerical comparison of 2D resistivity imaging with 10 electrode arrays: Geophysical Prospecting, v. 52, p. 379-398. doi:10.1111/j.1365-2478.2004.00423.x.

D'Alessandro, A., Massari, F., Davaud, E., and Ghibaudo, G., 2004, Pliocene-Pleistocene sequences bounded by subaerial unconformities within foramol ramp calcarenites and mixed deposits (Salento, SE Italy): Sedimentary Geology, v. 166, p. 89-144. doi:10.1016/j.sedgeo. 2003.11.017.

D’Alessandro, A., Mastronuzzi, G., Palmentola, G., and Sansò, P., 1994, Pleistocene deposits of Salento leccese (southern Italy): Problematic relationships: Bollettino della Società Paleontologica Italiana, v. 33, p. $257-263$.

this plot is identical to Figure 5c. The locations of boreholes S1 and S2 are shown. (d) Subsurface stratigraphy inferred from the geophysical data and drilling. The layers are labeled the same as in Figure 3: a, the Gravina Calcarenite overlying the Miocene basement rock; $b$, the Brachiopods sands; c, the Subapennine clays; d, the Brindisi sands; e, Terraced deposits; and f, top soil. The white box is a cavity intersected by borehole $\mathrm{S} 1$; the red box is symbolic of other cavities that may be the causes of other, less conspicuous features in the data. 
deGroot-Hedlin, C., and Constable, S., 1990, Occam's inversion to generate smooth, two-dimensional models from magnetotelluric data: Geophysics, v. 55, p. 1613-1624. doi:10.1190/1.1442813.

Fedi, M., 2007, DEXP: A fast method to determine the depth and the structural index of potential fields sources: Geophysics, v. 72, p. I1-I11. doi:10.1190/1.2399452.

Fedi, M., and Pilkington, M., 2012, Understanding imaging methods for potential field data: Geophysics:, v. 77, p. G13-G24. doi:1.1190/ geo2011-0078.1.

Gambetta, M., Armadillo, E., Carmisciano, C., Stefanelli, P., Cocchi, L., and Tontini, F.C., 2011, Determining geophysical properties of a near-surface cave through integrated microgravity vertical gradient and electrical resistivity tomography measurements: Journal of Cave and Karst Studies, v. 73, no. 1, p. 11-15. doi:10.4311/jcks2009ex0091.

Gibson, P.J., Lyle, P., and George, D.M., 2004, Application of resistivity and magnetometry geophysical techniques for near-surface investigations in karstic terranes in Ireland: Journal of Cave and Karst Studies, v. 66 , no. 2 , p. $35-38$.

Giudici, M., Margiotta, S., Mazzone, F., Negri, S., and Vassena, C., 2012, Modelling hydrostratigraphy and groundwater flow of a fractured and karst aquifer in a Mediterranean basin (Salento peninsula, southeastern Italy): Environmental Earth Sciences, v. 67, no. 7, p. 1891-1907. doi:10.1007/s12665-012-1631-1.

Gómez-Ortiz, D., and Martín-Crespo, T., 2012, Assessing the risk of subsidence of a sinkhole collapse using ground penetrating radar and electrical resistivity tomography: Engineering Geology, v. 149-150, p. 1-12. doi:10.1016/j.enggeo.2012.07.022.

Jol, H.M., 2009, ed., Ground Penetrating Radar: Theory and Applications, Amsterdam, Elsevier, 544 p.

Kaufmann, G., Romanov, D., and Nielbock, R., 2011, Cave detection using multiple geophysical methods: Unicorn cave, Harz Mountains, Germany: Geophysics, v. 76, no. 3, p. B71-B77. doi:10.1190/1.3560245.

Kotyrba, B., and Schmidt, V., 2014, Combination of seismic and resistivity tomography for the detection of abandoned mine workings in Münster/Westfalen, Germany: Improved data interpretation by cluster analysis: Near Surface Geophysics, v. 12, p. 415-425. doi:10.3997/1873-0604.2013056.

Leucci, G., Margiotta, S., and Negri, S., 2004, Geological and geophysical investigations in karstic environment (Salice Salentino, Lecce, Italy): Journal of Environmental and Engineering Geophysics, v. 9, p. 25-34.

Loke, M.H., 2014, Tutorial: 2-D and 3-D Electrical Imaging Surveys, PDF file at http://www.geotomosoft.com/coursenotes.zip, [accessed Nov. 2014].

Margiotta, S., Mazzone, F., and Negri, S., 2010, Stratigraphic revision of Brindisi - Taranto plain: Hydrogeological implications: Memorie Descriptive della Carta Geologica d'Italia, v. 90, p. 165-180.

Margiotta, S., Negri, S., Parise, M., and Valloni, R., 2012, Mapping the susceptibility to sinkholes in coastal areas, based on stratigraphy, geomorphology and geophysics: Natural Hazards, v. 62, p. 657-676. doi:10.1007/s11069-012-0100-1.

Margiotta, S., and Varola, A., 2007, Il paleosito di Cutrofiano (Salento), proposta per l'istituzione di un parco - museo. Atti della Società Toscana Di Scienze naturali - Memorie. Serie A 112,1-8.

Martínez-López, J., Rey, J., Dueñas, J., Hidalgo, C., and Benavente, J., 2013, Electrical tomography applied to the detection of subsurface cavities: Journal of Cave and Karst Studies, v. 75, no. 1, p. 28-37. doi:10.4311/2011ES0242.

Martínez-Pagán, P., Gómez-Ortiz, D., Martín-Crespo, T., Manteca, J.I., and Rosique, M., 2013, The electrical resistivity tomography method in the detection of shallow mining cavities: A case study on the Victoria Cave, Cartagena (SE Spain): Engineering Geology, v. 156, p. 1-10. doi:10.1016/j.enggeo.2013.01.013.

Mochales, T., Casas, A.M., Pueyo, E.L., Pueyo, O., Román, M.T., Pocoví, A., Soriano, M.A., and Ansón, D., 2008, Detection of underground cavities by combining gravity, magnetic and ground penetrating radar surveys: A case study from the Zaragoza area, NE Spain: Environmental Geology, v. 53, p. 1067-1077. doi:10.1007/ s00254-007-0733-7.

Parise, M., 2010, The impacts of quarrying in the Apulian karst, in Carrasco, F., LaMoreaux, J.W., Durán, J.J., and Andreo, B. eds., Advances in Research in Karst Media, Heidelberg, Springer Environmental Earth Sciences series, p. 441-447.

Parise, M., 2012, A present risk from past activities: Sinkhole occurrence above underground quarries: Carbonates and Evaporites, v. 27, no. 2, p. 109-118. doi:10.1007/s13146-012-0088-3.

Parise, M., and Lollino, P., 2011, A preliminary analysis of failure mechanisms in karst and man-made underground caves in Southern Italy: Geomorphology, v. 134, p. 132-143. doi:10.1016/j.geomorph. 2011.06.008.

Pueyo Anchuela, Ó., Pocoví Juan, A., Casas-Sainz, A.M., Ansón-López, D., and Gil-Garbi, H., 2013, Actual extension of sinkholes: Considerations about geophysical, geomorphological, and field inspection techniques in urban planning projects in the Ebro basin (NE Spain): Geomorphology, v. 189, p. 135-149. doi:10.1016/j.geomorph. 2013.01.024.

Reynolds, J.M., 1997, An Introduction to Applied and Environmental Geophysics, New York, Wiley, 796 p.

Ricchetti, G., Ciaranfi, N., Luperto Sinni, E., Mongelli, F., and Pieri, P., 1988, Geodinamica ed evoluzione sedimentaria e tettonica dell'Avampaese Apulo: Memorie della Società Geologica Italiana, v. 41, p. $57-82$.

Talwani, M., Worzel, J.L., and Landisman, M., 1959, Rapid gravity computations for two-dimensional bodies with application to the Mendocine submarine fracture zone: Journal of Geophysical Research, v. 64, p. 49-61. doi:10.1029/JZ064i001p00049. 